Cautious reception for British white paper on higher education

\section{London}

THE British government's white paper on higher education (see p.531) "raises more questions than it answers", according to a University of Cambridge spokesman, in a reaction echoed by universities and polytechnics throughout the country. Education administrators fear a far greater "interventionist role" in university operations and the direction of research, in the light of new proposals to tie financial support to an undefined system of contracts.

"This idea of contracts could lead to a university system directed to the needs of industry and commerce", said Sir Mark Richmond, the vice-chancellor of the University of Manchester.

The new University Funding Council (UFC) would use a system of contracting, according to the white paper, to "sharpen accountability for the use of public funds", and to "strengthen the commitment of higher education institutions to the delivery of educational services" agreed upon by the UFC.

The report gives no details about what would be included in the contracts, and educators are unclear if the new system would be linked with the number of students in a particular subject, their qualifications or other details. "Is the university going to have to produce 50 graduates, of whom ten get first class degrees", one administrator asked. "If the department doesn't deliver, will it be penalized?"

The government clearly intends to direct education and research into areas required by industry, with the underlying assumption that the increasingly diminishing resources would be selectively distributed. "But", said a University of Edinburgh spokesman, "if the emphasis is more towards applied research and education, it creates concern among the areas not directly related to immediate industrial well-being, in the arts, the social sciences, and to some extent parts of the sciences."

Under the new policy, Britain's polytechnics and colleges would be freed from the control of local education authorities, a proposal generally welcomed by the polytechnics. "Some local authority procedures are not geared to the provision of education", explained the director of the 6,000-student Coventry Polytechnic, Geoffrey Holroyde.

But the distribution of financial support to Britain's polytechnics would be determined by a new Polytechnics and Colleges Funding Council, which would, according to the white paper, "have a strong industrial and commercial element". In addition, the Secretary of State for Education and Science would have reserve powers of direction, a stronger role than he would take in the University Funding Council.

"This move on the polytechnics is highly political", said Richmond. "The government has been uneasy about the way the local authorities spend the money." There is some concern among polytechnic administrators that the government will intervene in the direction of these institutions to provide a kind of manpower planning for industrial and commercial interests.

One aspect of the white paper that has been welcomed is the decision to increase the number of students over the next decade, although the numbers will fall again by the mid-1990s. But the projected increase of 24,000 full-time and 27,000 parttime students has been criticized by the Committee of Vice-Chancellors and Principals as "too unambitious". Lack of funding for the increased numbers is also of concern - "the white paper is totally lacking in any indication of how the extra students are to be funded", said Sir John
Burnett, vice-chancellor of the University of Edinburgh, who points out that there is no proposal to increase student maintenance grants.

The government has also proposed increased autonomy for educational institutions in Scotland, with the provision for a Scottish Committee to provide input to the UFC on Scottish needs. This move is seen as a compromise, as the Scottish Tertiary Education Advisory Council recommendation for a separate funding system has not been supported by the Scottish universities. "We'll be very interested in seeing just what will be the standing of the input from the Scottish Committee", said a University of Edinburgh spokesman.

The government's recommendations on higher education are presented in a glossy booklet full of colourful graphics, in contrast to the usual stark white paper. It is seen by some education administrators as an election manifesto, because its provisions could not be implemented before the British election.

Higher education officials agree that there are many details to be supplied about the new proposals, before there can be any move to change policies. "There is going to be some very active lobbying going on," one official concluded.

Kathy Johnston

\title{
Judge confirms injunction in sandwich assay patent suit
}

\section{Washington}

IN the latest round in the court battle between Monoclonal Antibodies Inc. and Hybritech Inc. over the patent for sandwich assays, Monoclonal Antibodies has suffered a severe blow. As a follow-up to the court decision that upheld the contested Hybritech patent for the assays last fall, a US judge has confirmed that a preliminary injunction will be issued against Monoclonal Antibodies Inc. The injunction will prevent Monoclonal Antibodies from selling products that comprise 80 per cent of its product sales.

The dispute between Hybritech, a subsidiary of Eli Lilly, and Monoclonal Antibodies centres on 'sandwich assays', a technique for diagnosing physical conditions such as disease or pregnancy using monoclonal antibodies. Hybritech sued Monoclonal for patent infringement in 1984, and its patent was overturned in subsequent litigation due to obviousness. Hybritech appealed, and the appellate court upheld the Hybritech patent (see Nature 324, 506; 1986).

The preliminary injunction against Monoclonal Antibodies mainly affects its OvuStick test for determining ovulation, and Advance, a pregnancy kit made by Monoclonal and marketed by Ortho Phar- maceutical Corporation. The cost to Monoclonal of the injunction against sales of these products is estimated to be $\$ 1.1$ million a quarter.

Thomas A. Glaze, president of Monoclonal Antibodies, says the company will now focus on the development of products

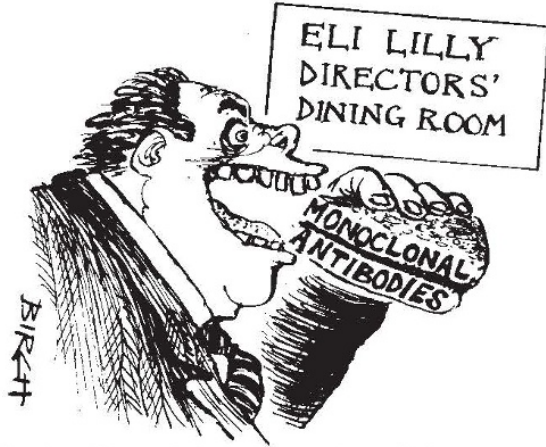

that will not be encumbered by patent problems. He hopes to introduce tests for sexually transmitted diseases and the detection of drug abuse in late 1987 or early 1988.

But the question of damages has not yet been solved, and a large award to Hybritech could further debilitate Monoclonal Antibodies. Industry analysts have already pinpointed Monoclonal as a possible takeover target.

Carol Ezzell 